\title{
STRUKTUR, PERILAKU DAN KINERJA PEMASARAN BIJI KAKAO DI KABUPATEN PARIGI MOUTONG PROVINSI SULAWESI TENGAH
}

\author{
Ihdiani Abubakar), Dedi Budiman Hakim²), dan Ratna Winandi Asmarantaka ${ }^{2)}$ \\ ${ }^{1)}$ Sekolah Pascasarjana, Institut Pertanian Bogor \\ ${ }^{2)}$ Departemen Ilmu Ekonomi, Fakultas Ekonomi dan Manajemen, Institut Pertanian Bogor \\ ${ }^{3)}$ Departemen Agribisnis, Fakultas Ekonomi dan Manajemen, Institut Pertanian Bogor \\ 1)ihdianiabubakar@yahoo.com
}

\begin{abstract}
Parigi Moutong is one of cocoa production center in the Central Sulawesi province. The problem faced by cocoa farmers in Parigi Moutong is the weak bargaining position of farmers in the price determination. The purpose of this study is to analyze cocoa beans market structure, conduct and performance at Parigi Moutong district. The methods used are market concentration and exit barriers to analyze market structure; market conductand farmer share and marketing margin to analyze market performance. The results show that the market of cocoa beans has four marketing channels which the highest total margin is on $2^{\text {nd }}$ channel (Rp 25465 and oligopsony structure. The most efficient marketing channel is channel 3 with 58.01 percent of farmer share. One of alternatives to increase farmer's bargaining position in determining the cocoa price is by improving the cocoa quality through fermentation. This can be conducted by the farmer empowerment systematically and sustainably.
\end{abstract}

Keyword(s): market structure-conduct-performance, cocoa beans

\begin{abstract}
ABSTRAK
Kabupaten Parigi Moutong merupakan kabupaten sentra produksi kakao di Provinsi Sulawesi Tengah. Masalah mendasar yang dihadapi petani kakao di Parigi Moutong adalah posisi tawar petani yang lemah dalam penentuan harga. Tujuan penelitian ini adalah menganalisis struktur, perilaku dan kinerja pasar biji kakao di Kabupaten Parigi Moutong. Metode penelitian yang digunakan adalah struktur pasar yang dianalisis dengan konsentrasi pasar dan hambatan keluar masuk pasar, serta perilaku pasar dan kinerja pasar yang dianalisis dengan farmer share dan marjin pemasaran. Hasil penelitian menunjukkan bahwa pemasaran biji kakao memiliki empat saluran pemasaran, pasar bersifat oligopsoni, posisi petani sebagai penerima harga dan adanya hambatan masuk pasar karena peranan pedagang pengumpul. Total marjin yang tetinggi terdapat pada saluran 2 (petani-pedagang desa-pedagang kecamatan-eksportir) yaitu sebesar Rp 25.465. Saluran pemasaran yang paling efisien adalah saluran pemasaran 3 dengan nilai farmer share sebesar 58,01 persen. Alternatif untuk meningkatkan posisi tawar petani dalam proses penentuan harga yaitu perbaikan mutu kakao dengan cara melakukan fermentasi. Hal ini dapat dilakukan dengan program pemberdayaan petani yang dilakukan secara sistematis dan berkelanjutan. Sehingga perkembangan kebutuhan pasar segera di respon oleh petani.
\end{abstract}

Kata Kunci: struktur-perilaku-kinerja pemasaran, biji kakao 


\section{PENDAHULUAN}

Kakao merupakan salah satu komoditi unggulan perkebunan yang mempunyai peranan penting dalam perekonomian Indonesia. Peran tersebut terwujud dalam bentuk penyedia lapangan kerja, sumber pendapatan dan devisa negara, sumbangan devisa negara pada Tahun 2013 melalui ekspor komoditas kakao sebesar US\$ 794,8 juta. Tujuan ekspor biji kakao Indonesia antara lain Amerika Serikat, Malaysia, Singapura, Brasil dan Perancis. Pangsa pasar terbesar biji kakao Indonesia adalah Amerika Serikat sebesar 21\%, Malaysia sebesar $47 \%$, serta Singapura sebesar 12\% (Ditjenbun, 2014)

Pada Tahun 2013, perkebunan kakao telah menyediakan lapangan kerja dan sumber pendapatan bagi sekitar 1.237.119 kepala keluarga petani yang sebagian besar berada di Kawasan Timur Indonesia (KTI) serta memberikan sumbangan devisa terbesar ke tiga sub sektor perkebunan setelah karet dan kelapa sawit dengan nilai sebesar US \$1,05 miliar (BPS, 2010). Mengingat besarnya potensi komoditas ini dalam perekonomian, dengan demikian pengembangan komoditas ini terus dilakukan. Dalam 15 tahun terakhir luas perkebunan kakao meningkat pesat dari 749.917 hektar pada Tahun 2000 menjadi 1.736.403 hektar pada Tahun 2013 dan produksi meningkat dari 421.142 ton pada tahun 2000 menjadi 938.843 ton pada tahun 2013 (Ditjenbun, 2014).

Kakao merupakan tanaman yang dapat tumbuh dengan baik hampir di seluruh wilayah Sulawesi Tengah. Di Sulawesi Tengah tanaman kakao banyak ditemui di Kabupaten Donggala, Parimo, Poso, Marowali, Tojo Una-Una, ToliToli, Banggai dan Banggai kepulauan. Kegiatan produksi masih pada tingkat pengeringan secara tradisional. Untuk sarana pendukung perkebunan kakao cukup tersedia, yakni pelabuhan interinsuler di daerah areal perkebunan. Selain itu jalan darat ke sentra-sentra produksi biji kakao di Sulawesi Tengah juga memadai. (Yantu, 2008)

Luas lahan kakao di Sulawesi Tengah pada tahun 2009 sebesar 224.113 ha sedangkan pada tahun 2012 mengalami peningkatan sebesar 295.874 ha. Tetapi pada tahun 2013 menurun menjadi 284.125 ha. Dari sisi produksi dari tahun ke tahun mengalami peningkatan, dimana pada tahun 2009 produksi biji kakao Sulawesi Tengah 137.651 ton dan menjadi 195.846 ton pada tahun 2013 (BPS, 2013).

Potensi pengembangan kakao di Sulawesi Tengah cukup besar, namun belum seluruh areal potensial dimanfaatkan. Ada banyak pedagang, lembaga pemasaran maupun pemerintah, dengan kepentingannya masing-masing ikut berperan dalam pemasaran biji kakao. Sementara kualitas biji kakao yang dihasilkan petani belum memiliki standar yang jelas. Hal ini akan mempengaruhi proeses pemasarannya karena mekanisme pembentukan harga biji kakao di pasar akan berdampak langsung pada perilaku partisipan yang terlibat dalam perdagangan komoditas ini. Eksportir, pedagang lokal, pedagang pengumpul dan petani sendiri, adalah pihak yang akan terkena dampak harga. Seberapa besar dampak harga yang dihadapi oleh 
lembaga pemsaran biji kakao sangat tergantung pada kekuatan masing-masing pelaku yang terlibat dalam rantai pemasaran biji kakao itu sendiri, (Yantu, 2011)

Keadaan pasar biji kakao seperti yang digambarkan di atas berpotensi menimbulkan masalah dan bisa merugikan petani sebagai produsen. Pola pemasaran yang terjadi cenderung tidak efisien karena melibatkan pelaku pemasaran yang banyak dengan kepentingan yang berbeda-beda. Menurut penelitian Yantu (2011) pola pemasaran biji kakao di Sulawesi Tengah adalah melalui pedagang pengumpul, pedagang besar dan eksportir, merupakan pola pemasaran biji kakao yang secara tradisional masih tetap bertahan sampai saat ini.

Nurhidayah (2014) dalam penelitiannya mengemukakan bahwa daya tawar petani juga cenderung rendah karena jumlah petani sangat banyak dan tersebar di berbagai wilayah, belum adanya koordinasi dan kerjasama antar petani, persaingan pasar yang semakin kompetitif, lokasi konsumen akhir biji kakao yang jauh dari sentra produksi (di luar negeri) dan belum adanya rantai distribusi yang jelas dari petani sampai ke industri berbahan baku biji kakao, ditambah lagi dengan masalah produksi dan mutu seperti yang telah diuraikan di atas. Perilaku harga akan cenderung didominasi oleh kepentingan pedagang besar dan eksportir.

Sistem pemasaran biji kakao tidak terlepas dari penentuan harga. Harga yang ditentukan oleh pedagang pengumpul sebenarnya sangat bergantung pada harga di tingkat eksportir dan pasar dunia. Harga tersebut terbentuk karena permintaan dan penawaran biji kakao oleh negara konsumen. Fluktuasi harga di pasar dunia seharusnya juga berpengaruh terhadap harga jual biji kakao di tingkat petani. Namun tingginya harga jual biji kakao oleh eksportir belum sepenuhnya dirasakan oleh petani, (Amalia, 2013). Salah satu upaya mengatasi permasalahan di dalam sistem pemasaran yaitu dengan menganalisis sistem pemasaran menggunakan pendekatan struktur pasar (market structure), perilaku pasar (market conduct) dan kinerja pasar (market performance) (SCP) (Bosena et al. 2011; Funke et al.2012

Secara teoritik harga biji kakao ditentukan oleh struktur pasar, perilaku lembaga pemasaran dan kinerja pasar biji kakao tersebut. Struktur pasar yang terbentuk akan menentukan sistem penetapan harga biji kakao bila dilihat dari banyaknya lembaga yang terlibat dan posisi lembaga tersebut pada pasar. Jika produsen memiliki market power yang cukup besar maka dengan mudah dapat mempengaruhi harga jual biji kakao di pasar, hal ini terkait juga dengan jumlah pedagang yang terlibat pada proses penjualan, apabila hanya terdapat sedikit pedagang pengumpul atau eksportir maka petani cenderung tidak memiliki pilihan menjual biji kakao yang diproduksi apalagi harga yang ditetapkan relatif sama. Dalam proses penentuan harga biji kakao juga tidak terlepas dari keterkaitan antar lembaga pemasaran didalamnya. Keterkaitan tersebut berkaitan dengan fungsi-fungsi yang dilakukan oleh lembaga pemasaran dan kerjasama yang 
terjalin antar lembaga pemasaran. Adapun masalah yang dikaji dalam penelitian ini ialah : Bagaimana struktur, perilaku dan kinerja pasar biji kakao di Kabupaten Parigi Moutong? Berdasarkan uraian tersebut, maka kajian struktur, perilaku dan kinerja pemasaran biji kakao penting dilakukan untuk menjawab pertanyaan tersebut. Oleh karena itu penelitian ini bertujuan untuk menganalisis struktur, perilaku, dan kinerja pasar biji kakao di Kabupaten Parigi Moutong.

\section{KERANGKA PEMIKIRAN}

\section{Teori Pemasaran}

Definisi tentang pemasaran telah banyak dikemukakan oleh para ahli ekonomi, pada hakekatnya bahwa pemasaran merupakan aktivitas yang ditujukan terhadap barang dan jasa sehingga dapat berpindah dari tangan produsen ke tangan konsumen. Pemasaran menurut Kohls dan Uhl (2002) merupakan sebuah sistem meliputi seluruh aliran produk dan jasa-jasa yang ada, mulai dari titik awal produksi pertanian sampai semua produk dan jasa tersebut ditangan konsumen. Menurut Downey et al (1981) kompleksitas saluran pemasaran tergantung pada masing-masing komoditi. Pemasaran melibatkan banyak perbedaan aktivitas yang dapat memberikan nilai tambah terhadap suatu produk sebagai perubahan melalui suatu sistem. Sistem pemasaran merupakan suatu kegiatan yang produktif, sangat kompleks, sesuai dengan ketetapan, dan menimbulkan biaya.
Menurut Dahl dan Hammond (1977) pemasaran diinterpretasikan sebagai suatu unit fungsi. Kekuatan permintaan dan penawaran yang terjadi biasanya dipengaruhi oleh harga dan tempat terjadinya proses perpindahan kepemilikan barang dan jasa melalui transaksi. Kohls dan Uhl (2002) menambahkan dalam menganalis pemasaran dapat digunakan beberapa pendekatan antara lain pendekatan fungsi (the functional approach), pendekatan kelembagaan (the institutional approach), dan pendekatan sistem (the system approach).

Kohl dan Uhl (2002) mendefinisikan pasar sebagai suatu arena untuk mengatur dan menfasilitasi aktivitas bisnis serta untuk menjawab pertanyaan-pertanyaan dasar ekonomi mengenai: produk apa yang dihasilkan, berapa banyak produksi, bagaimana cara memproduksi, dan bagaimana produk didistribusikan. Sedangkan menurut Dahl and Hammond (1977), secara garis besar pasar merupakan sejumlah lingkungan atau tempat dimana, (1) kekuatan permintaan dan penawaran saling bertemu, (2) terbentuk harga serta perubahan harga terjadi, (3) terjadinya perpindahan kepemilikan sejumlah barang dan jasa dan, (4) beberapa susunan fisik dan institusi dibuktikan. Terdapat beberapa pendekatan untuk menganalisis sistem pemasaran Kohl dan Uhl (2002), yaitu: (1) Pendekatan serba fungsi, adalah pendekatan yang mempelajari jenis usaha yang dilakukan oleh pelaku pemasaran yang terlibat dalam pemasaran, bagaimana cara melakukan kegiatan pemasaran, mengapa dilakukan, dan siapa pelaku pemasaran yang terlibat. (2) 
Pendekatan serba lembaga, adalah pendekatan yang mempelajari berbagai macam lembaga pemasaran yang melakukan tugas pemasaran, bagaimana tugas tersebut dilakukan, dan barang apa yang dikendalikan. (3) Pendekatan serba barang adalah pendekatan yang mempelajari berbagai barang yang dipasarkan dan sumber barang.

Menurut Abbott dan Mahekam (1990) bahwa terdapat beberapa hal yang dapat menunjang keberhasilan suatu proses pemasaran yaitu (1) Pengaturan pasar. Pemasaran dapat berjalan dengan baik apabia ada kekuatan legal yang memaksa dalam perjanjian dan adanya perlindungan yang melawan praktek kecurangan. (2) Informasi pasar. Informasi sangat diperlukan bagi produsen, pedagang dan konsumen untuk terjadinya efisiensi dalam mekanisme pasar. (3) Penelitian pasar. Membangun dan meningkatkan pemasaran sangat diperlukan penelitian pasar, karena penelitian pasar dapat mengarahkan invesatasi dan kebijakan pemasaran serta menurunkan biaya sehingga meningkatkan efisiensi. (4) Penyuluhan dan pelatihan. Bertujuan untuk meningkatkan kinerja lembaga pemasaran sehingga proses pemasaran lebih terorganisir sehingga akan meningkatkan efisiensi dan efektivitas pada sistem pemasaran tersebut. (5) Promosi produk.

Pemasaran dapat ditinjau dari dua perspektif yaitu perspektif makro dan mikro (Asmarantaka 2012). Perspektif makro menganalisis sistem pemasaran setelah dari petani yaitu fungsi-fungsi pemasaran untuk menyampaikan produk atau jasa yang berhubungan dengan nilai guna, waktu, bentuk, tempat, dan kepemilikan kepada konsumen serta kelembagaan yang terlibat dalam sistem pemasaran. Perspektif mikro menekankan pada aspek manajemen dimana perusahaan secara individu dalam setiap tahapan pemasaran mencari keuntungan. Keseluruhan pendekatan ini akan menganalisis keseluruhan sistem pemasaran dari aspek makro, mulai dari pendekatan fungsi, kelembagaan, pengolah/ pabrikan, organisasi fasilitas, dan sistem merupakan suatu kajian empiris dan deskriptif dalam aliran atau rantai pemasaran dari produsen primer sampai ke konsumen akhir. Seluruh pendekatan tersebut merupakan bagian yang terkait dalam sistem pemasaran dengan pendekatan SCP (structure, conduct dan performance).

\section{Konsep Struktur, Perilaku, dan Kinerja (SCP) serta \\ Perkembangannya}

Paradigma SCP pada awalnya merupakan salah satu pendekatan untuk mengkaji pembentukan organisasi industri. Carlton dan Perlof (2000), mengemukakan bahwa dalam perkembangannya kerangka SCP telah menjadi kerangka umum pendekatan kajian organisasi industri. Paradigma SCP dicetuskan oleh Mason tahun 1939 yang mengemukakan bahwa struktur suatu industri akan menentukan bagaimana pelaku industri berperilaku yang menentukan kinerja industri tersebut.

Asmarantaka (2012) mengajukan konsep yang bersifat dinamis. Keterkaitan hubungan dua arah yang bersifat timbal balik dan sifat hubungan 
endogenous diantara variabel-variabel SCP serta memperhitungkan waktu. Pendekatan tersebut menunjukkan bahwa structure (S), conduct (C), dan performance $(\mathrm{P})$ dalam suatu waktu berada pada sistem dimana $\mathrm{S}$ dan $\mathrm{C}$ adalah faktor penentu dari $\mathrm{P}$, di lain waktu S dan $\mathrm{C}$ ditentukan oleh P. Hal ini menunjukkan suatu sistem dinamis yang mengembangkan respon penyesuaian dari perusahaan terhadap kondisi pasar dan keadaan yang memungkinkan. Pertama struktur mempengaruhi perilaku, semakin tinggi konsentrasi maka semakin rendah tingkat persaingan di pasar. Kedua perilaku mempengaruhi kinerja, semakin rendah tingkat persaingan maka akan semakin tinggi market power atau semakin tinggi keuntungan perusahaan. Ketiga struktur mempengaruhi kinerja, semakin tinggi tingkat konsentrasi pasar maka akan semakin rendah tingkat persaingan dan market power semakin tinggi.

Rosiana (2012) mengemukakan bahwa terdapat beberapa indikator dalam menentukan efisiensi pemasaran dengan pendekatan SCP. Indikator dalam struktur pasar seperti jumlah pedagang, hambatan masuk, ada tidaknya kolusi pasar, dan konsentrasi pasar. Sedangkan indikator dari analisis perilaku pasar yaitu penentuan dan pembentukan harga. Analisis kinerja pasar yang menjadi indikator yaitu share produsen, distribusi margin, integrasi pasar, dan elastisitas transmisi harga. Indikator pada analisis pemasaran dengan pendekatan SCP (struktur, perilaku dan kinerja).

Waldman dan Jansen (2007) mengemukakan paradigma SCP dibangun berdasarkan analisis yang saling ber- hubungan. market condition yang dipengaruhi oleh kondisi permintaan dan penawaran yang akan menentukan struktur pasar. Struktur pasar (market structure) menunjukkan perilaku pasar (market conduct) dan perilaku pasar akan menunjukkan kinerja pasar (market performance). Kebijakan pemerintah dalam pasar persaingan tidak sempurna dapat mempengaruhi struktur, perilaku, dan kinerja pasar. Kinerja pasar suatu waktu dapat mempengaruhi struktur dan perilaku pasar demikian pula sebaliknya.

Kondisi permintaan dan penawaran terkait erat dengan elastisitas harga, keberadaan barang subtitusi, pertumbuhan pasar, jenis barang, tekhnologi, bahan baku, skala ekonomi dan lain-lain. Struktur pasar merupakan bentuk pasar yang mempengaruhi tingkat persaingan dalam suatu industri. Identifikasi struktur pasar terdiri atas banyaknya jumlah perusahaan yang bersaing dalam pasar, efisiensi produk, penggunaan teknologi, konsentrasi pasar, dan hambatan keluar masuk pasar.

\section{METODE PENELITIAN}

\section{Lokasi dan Waktu Penelitian}

Penelitian dilakukan di sentra kakao di Kabupaten Parigi Moutong, yaitu Kecamatan Ampibabo dengan dua desa sebagai yaitu Desa Buranga dan Ampibabo. Lokasi dipilih secara purposive atas pertimbangan desa tersebut merupakan kedua desa dengan produksi dan luas lahan terbesar di Kecamatan Ampibabo. Penelitian dilakukan sejak bulan Maret 2015. 


\section{Metode Pengambilan Sampel}

Pengambilan sampel petani kakao adalah stratified random sampling atau sampel acak terstratifikasi. Proses stratifikasi dilakukan karena luas lahan kepemilikan yang heterogen. Populasi dibagi menjadi 4 strata berdasarkan luas lahan masing-masing petani kakao, yaitu (1) luas lahan antara 0,1 sampai 1 ha sebanyak 41 responen, (2) luas lahan 1,1 sampai 2 ha sebanyak 22 responden, (3) luas lahan 2,1 sampai 3 ha sebanyak 12 responden dan (4) luas lahan lebih besar dari 3 ha sebanyak 5 responden.

Pengambilan sampel pedagang menggunakan metode snow ball sampling. Jumlah sampel pedagang pengumpul desa sebanyak 4 responden, pedagang pengumpul kecamatan sebanyak 4 Pedagang besar provinsi sebanyak 2, dan eksportir sebanyak 2 responden.

\section{Metode Analisis Data}

Metode analisis yang digunakan dalam penelitian ini adalah analisis struktur pasar (konsentrasi pasar dan hambatan keluar masuk pasar), analisis perilaku pasar dan analisis kinerja pasar (marjin pemasaran dan farmer share).

\section{Analisis Struktur Pasar}

Komponen struktur pasar yang diteliti meliputi konsentrasi pasar dan hambatan keluar masuk pasar.

\section{Konsentrasi pasar}

Perhitungan konsentrasi pasar menggunakan rasio antara penjualan suatu eksportir terhadap total penjualan kakao di Provinsi Sulawesi Tengah. Untuk konsentrasi pasar, digunakan analisis Four Firm Concentration Ratio (CR4). Nilai CR4 mendekatai 0 diindikasikan berada pada pasar yang memiliki banyak penjual, yang memberikan peningkatan banyaknya persaingan antar produsen untuk menjualnya ke konsumen. Namun, jika nilai CR4 mendekati 1 diindikasikan pasar mengalami sedikit persaingan (pasar terkonsentrasi) antar produsen untuk menjualnya ke konsumen (Baye, 2010), Hirschey (2009) menambahkan apabila CR4 $\geq 0,8$ menunjukkan industri tersebut sangat terkonsentrasi, $0,5<\mathrm{CR}<0,8$ pasar terkonsentrasi sedang dan $\leq 0,5$ pasar terkonsentrasi lemah. Analisis struktur pasar dengan pendekatan CR4 pernah dilakukan Asmara dan Ardhiani (2010).

$$
\mathrm{CR} 4=\left(\mathrm{S}_{1}+\mathrm{S}_{2}+\mathrm{S}_{3}+\mathrm{S}_{4}\right) / \mathrm{S}_{\mathrm{n}}
$$

$$
\begin{aligned}
& \text { Keterangan: } \\
& \begin{aligned}
\mathrm{CR} 4= & \text { Konsentrasi rasio } \\
\mathrm{S}_{1,2,3,4}= & \text { Volume penjualan biji kakao oleh } \\
& \text { eksportir 1,2,3,4 (kg/bulan) } \\
\mathrm{Sn} & \text { Total penjualan seluruh eksportir biji } \\
& \text { kakao di Provinsi Sulawesi Tengah } \\
& (\mathrm{kg} / \mathrm{bulan})
\end{aligned}
\end{aligned}
$$

\section{Hambatan Keluar Masuk Pasar}

Hambatan masuk pasar dapat dianalisis dengan menggunakan Minimum Efficiency Scale (MES). Analisis ini dilakukan untuk melihat banyaknya perusahaan yang dapat masuk untuk bersaing merebut pangsa pasar. Nilai MES diperoleh dari pembelian biji kakao perusahaan (eksportir) terbesar terhadap total biji kakao dari Provinsi Sulawesi Tengah. Kajian struktur pasar dengan 
pendekatan MES pernah dilakukan oleh Burhan et al (2011) dengan hasil MES sebesar 18,75 persen. Menurut Jaya (2001), jika nilai MES lebih besar dari 10 persen mengindikasikan bahwa terdapat hambatan masuk pasar pada pemasaran biji kakao.

$$
M E S=\frac{\text { Penjualan eksportir terbesar }}{\text { Total ekspor biji kakao }} \times 100 \%
$$

\section{Analisis Perilaku Pasar}

Perilaku pasar merupakan perilaku partisipan (pembeli dan penjual). Strategi atau reaksi yang dilakukan partisipan pasar secara individu atau kelompok dalam hubungan kompetitif atau negosiasi terhadap partisipan lainnya untuk mencapai tujuan pemasaran dalam struktur pasar tertentu. Hubungan antara pembeli dan penjual merupakan hubungan persaingan. Setelah ada kesepakatan, maka terjadi transaksi atau negosiasi (Asmarantaka, 2008). Perilaku perusahaan memiliki kekuatan pemutusan pasar terdiri dari pasar monopoli, oligopoli, dan pasar persaingan sempurna. Perilaku pasar dianalisis secara deskriptif yaitu menjelaskan praktek penentuan harga yang dilakukan pedagang, meliputi cara pengujian kualitas, dan pemotongan harga. Perilaku pasar juga dianalisis secara kuantitatif.

\section{Analisis Kinerja Pasar}

Ukuran yang digunakan dalam melakukan analisis kinerja pasar adalah marjin pemasaran dan farmer share.

\section{Marjin Pemasaran}

Analisis pemasaran merupakan perbedaan harga yang diterima oleh petani kakao $\left(\mathrm{P}_{\mathrm{f}}\right)$ dengan harga yang dibayarkan oleh eksportir $\left(\mathrm{P}_{\mathrm{e}}\right)$. Untuk menganalisis margin pemasaran dalam penelitian ini, data harga yang digunakan adalag data harga tingkat petani kakao dan data harga di tingkat eksportir. Adapun rumus dari marjin pemasaran dapat dilihat sebagai berikut:

$$
\mathrm{MT}=\mathrm{Pe}-\mathrm{Pf}
$$

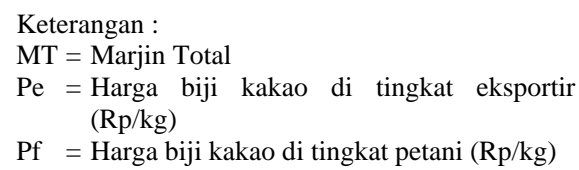

\section{Farmer Share}

Farmer Share merupakan rasio antara harga di tingkat petani terhadap harga di tingkat pedagang. Pada saluran pemasaran yang berbeda maka share harga yang diterima petani akan berbeda pula. Besarnya Farmer's share dipengaruhi oleh tingkat pemprosesan, biaya transportasi, keawetan produk dan jumlah produk (Kohl dan Uhl, 2002). Secara matematis farmer share dapat dilihat sebagai berikut :

$$
F_{s}=\frac{P f}{P e} \times 100 \%
$$

\footnotetext{
Dimana :

$\mathrm{F}_{\mathrm{s}}=$ Bagian harga yang diterima petani biji kakao (Rp/Kg)

$\mathrm{P}_{\mathrm{e}}=$ Harga biji kakao di tingkat eksportir $(\mathrm{Rp} / \mathrm{Kg})$

$\mathrm{P}_{\mathrm{f}}=$ Harga biji kakao di tingkat petani $(\mathrm{Rp} / \mathrm{Kg})$
} 
HASIL DAN PEMBAHASAN

\section{Analisis Struktur Pasar}

\section{Konsentrasi Pasar}

Hasil analisis konsentrasi pasar (CR4) menunjukkan bahwa terdapat empat perusahaan terbesar yang menguasai 70,45 persen dari total penjulan biji kakao di Provinsi Sulawesi Tengah. Artinya tingkat persaingan perusahaan biji kakao di Provinsi Sulawesi tengah terkonsentrasi dengan tingkat persaingan kecil hal ini dikarenakan terdapat 4 (empat) perusahaan terbesar yang menguasai penjualan biji kakao di Provinsi Sulawesi Tengah. Konsentrasi pasar yang tinggi dicirikan dengan nilai CR4 yang berkisar antara 60 hingga 80 persen artinya perusahaan semakin terkonsentrasi dan semakin sedikit jumlah produsen yang berada di pasar maka tingkat persaingan kecil. (Jaya, 2001).

Kohls dan Uhl (2002) menyatakan bahwa apabila CR4 perusahaan terbesar lebih dari 50 persen, maka struktur pasar cenderung berada pada kondisi pasar oligopoli dan petani menghadapi oligopsoni. Konsekuensi bagi petani dalam menghadapi struktur pasar oligopsoni adalah petani cenderung sebagai penerima harga (price taker) dan posisi tawar petani lemah (bargaining position) yakni petani tidak memiliki kekuatan dalam menentukan harga jual biji kakao yang dihasilkan.

\section{Hambatan Keluar Masuk Pasar}

Hambatan masuk pasar dihitung menggunakan Minimum Efficiency
Scale (MES). Nilai MES diperoleh dari volume penjualan biji kakao oleh perusahaan terbesar di Provinsi Sulawesi Tengah terhadap total penjulan biji kakao di Sulawesi Tengah pada tahun 2008 sampai 2013, artinya bila nilai MES > 10\% mengindikasikan terdapat hambatan masuk pasar bagi perusahaan baru (Jaya, 2001).

Pada tahun 2009 nilai MES sebesar 24,16 persen dan pada tahun 2013 mencapai 27,21 persen. Nilai rata-rata MES dari tahun 2009 hingga 2013 mencapai 22,65 persen artinya nilai MES lebih dari 10 persen. Hal ini mengindikasikan adanya hambatan masuk dalam perdagangan kakao di tingkat perusahaan (eksportir). Artinya angka tersebut merupakan indikator output minimal bagi pesaing baru untuk bersaing dalam industri kakao di Sulawesi Tengah. Bagi perusahaan, tingginya hambatan masuk pasar antara lain disebabkan oleh beberapa faktor yaitu oleh besarnya modal yang dibutuhkan, kerjasama antar perusahaan dan jaringan rantai pasok bahan baku yang kuat dengan pedagang pengumpul dan petani.

\section{Analisis Perilaku Pasar}

Perilaku pasar biji kakao di Provinsi Sulawesi Tengah dianalisis secara deskriptif. Analisis perilaku pasar akan menggambarkan perilaku setiap lembaga pemasaran dalam menghadapi struktur pasar yang ada. Adapun elemen yang terdapat dalam perilaku pasar meliputi lembaga dan praktek fungsi pemasaran, 
saluran pemasaran, mekanisme penentuan harga dan sistem pemasaran.

\section{Petani}

Kualitas biji kakao sangat dipengaruhi oleh pengolahan hasil. Ada beberapa aktivitas pengolahan hasil kakao setelah panen, yang menentukan kualitas biji kakao. Aktivitas-aktivitas tersebut adalah pemeraman buah kakao, pengeringan, penyortiran, dan penyimpanan. Kinerja aktivitas pengolahan hasil kakao di Parigi Moutong yang diukur dengan persentase petani responden yang melakukan aktivitas tersebut. Tidak semua petani responden di Sulawesi tengah melakukan pemeraman buah kakao. Hanya ada sekitar 53.75 persen yang melakukan aktivitas tersebut. Tampak bahwa di Kabupaten Parigi Moutong petani responden yang belum mengikuti program Sekolah Lapang yang melakukan aktivitas ini hanya mencapai 95 persen. Ini berarti ada sekitar 5 persen petani responden tersebut yang belum melakukan pengeringan. Menurut pengakuan petani yang tidak melakukan aktivitas pengeringan ini, mereka menjual kakao basah langsung ke pedagang, karena kekurangan tenaga kerja.

Sebagian besar petani responden melakukan aktivitas tersebut selama 4 hari. Semua petani responden melakukan pengeringan dengan penjemuran. Padahal sebagaimana dikemukakan oleh Yantu (2011) bahwa pada keadaan selalu ada sinar matahari, penjemuran membutuhkan waktu sampai 7 hari. Kurangnya lama hari penjemuran yang dilakukan oleh petani, menyebabkan kadar air yang disyaratkan oleh pedagang, yaitu 7 persen tidak tercapai, dan harga biasanya dipotong oleh pedangan sesuai kadar air biji kakao. Pedagang pengumpul biasanya menjemur kembali kakao biji hingga 3 hari agar mencapai kadar air $6-7$ persen. Ini dilakukan dengan tujuan agar biji kakao meskipun disimpan lama tidak mudah rusak.

\section{Pedagang Pengumpul Desa}

Pedagang pengumpul desa menghubungkan petani kakao dengan pedagang-pedagang tingkat selanjutnya. Pedagang pengumpul desa mengumpulkan biji kakao dari petani yang berada di lingkungan desanya dan sekitar desanya. Pedagang pengumpul desa umumnya bertempat tinggal di lokasi desa yang sama atau bahkan bisa datang dari desa sekitar. Beberapa pedagang pengumpul desa yang terdapat di Kabuapten Parigi Moutong juga berprofesi sebagai petani. Petani tersebut merupakan petani yang mempunyai modal cukup dalam melakukan kegiatan usaha ini.

Pedagang pengumpul desa tidak melakukan pengolahan sehingga biji kakao yang dibeli dari petani hanya disimpan sebelum dijual kembali pada lembaga pemasaran berikutnya. Beberapa pedagang pengumpul desa melakukan peminjaman kepada pedagang dengan tingkat yang lebih besar. Pedagang pengumpul desa memperoleh informasi pasar dari pedagang pengumpul kecamatan, pedagang pengumpul tingkat kabupaten dan pedagang besar. Informasi yang diterima diantaranya mengenai perkembangan harga jual dan juga kualitas biji kakao. 


\section{Pedagang Pengumpul Kecamatan}

Pedagang pengumpul kecamatan adalah pedagang yang menampung penjualan biji kakao masih dalam lingkup satu kecamatan. Sama seperti dengan pedagang pengumpul desa, pedagang pengumpul kecamatan merupakan anggota rantai pasok biji kakao yang berperan penting. Transaksi pembelian dapat dilakukan di tempat pengumpul yang lingkupnya kecil dan mendatangi langsung atau menunggu di rumah pedagang. Sebagian besar pedagang pengumpul kecamatan sudah mempunyai pedagang pengumpul lingkup lebih kecil yang menjadi langganan. Setiap pedagang pengumpul kecamatan memberikan harga tergantung kualitas biji kakao yang dijual. Begitu juga penjualan yang dilakukan pedagang pengumpul kecamatan ke pedagang berikutnya yang sesuai dengan kualitas biji kakao.

\section{Pedagang Besar Provinsi}

Pedagang besar provinsi menampung penjualan dalam lingkup satu Provinsi. Transaksi pembelian biji kakao biasanya dilakukan di tempat pengumpul yang lingkupnya lebih kecil dengan mendatangi langsung, atau petani yang mendatangi langsung ke pedagang besar provinsi. Pedagang besar provinsi biasanya sudah mempunyai jaringan pemasaran yang tertata dengan baik dan pedagang pengumpul lingkup lebih kecil yang sudah menjadi langganan. Pedagang besar Provinsi menggunakan mobil truk untuk mempermudah kegiatan pembelian

Tabel 1. Fungsi-fungsi Pemasaran yang dilakukan Masing-Masing Lembaga Pemasaran di Kabupaten Parigi Moutong, 2015

\begin{tabular}{|c|c|c|c|c|c|c|c|c|}
\hline \multirow{3}{*}{$\begin{array}{c}\text { Saluran dan } \\
\text { Lembaga } \\
\text { Pemasaran }\end{array}$} & \multicolumn{8}{|c|}{ Fungsi - Fungsi Pemasaran } \\
\hline & \multicolumn{2}{|c|}{ Pertukaran } & \multicolumn{2}{|c|}{ Fisik } & \multicolumn{4}{|c|}{ Faslititas } \\
\hline & Beli & Jual & $\begin{array}{c}\text { Peng- } \\
\text { angkutan }\end{array}$ & $\begin{array}{c}\text { Penyim- } \\
\text { panan }\end{array}$ & Sortasi & Resiko & $\begin{array}{c}\text { Pem- } \\
\text { biayaan }\end{array}$ & $\begin{array}{c}\text { Informasi } \\
\text { Pasar }\end{array}$ \\
\hline \multicolumn{9}{|l|}{ Saluran 1} \\
\hline Petani & $\times$ & $\sqrt{ }$ & $\sqrt{ }$ & $\times$ & $\sqrt{ }$ & $\sqrt{ }$ & $\times$ & $\sqrt{ }$ \\
\hline PPKec & $\sqrt{ }$ & $\sqrt{ }$ & $\sqrt{ }$ & $\sqrt{ }$ & $\sqrt{ }$ & $\sqrt{ }$ & $\sqrt{ }$ & $\sqrt{ }$ \\
\hline PBProv & $\sqrt{ }$ & $\sqrt{ }$ & $\sqrt{ }$ & $\sqrt{ }$ & $\sqrt{ }$ & $\sqrt{ }$ & $\sqrt{ }$ & $\sqrt{ }$ \\
\hline Eksportir & $\sqrt{ }$ & $\sqrt{ }$ & $\sqrt{ }$ & $\sqrt{ }$ & $\sqrt{ }$ & $\sqrt{ }$ & $\sqrt{ }$ & $\sqrt{ }$ \\
\hline \multicolumn{9}{|l|}{ Saluran 2} \\
\hline Petani & $x$ & $\sqrt{ }$ & $\sqrt{ }$ & $\times$ & $\times$ & $\sqrt{ }$ & $x$ & $\sqrt{ }$ \\
\hline PPDesa & $\sqrt{ }$ & $\sqrt{ }$ & $\sqrt{ }$ & $\sqrt{ }$ & $\times$ & $\sqrt{ }$ & $\sqrt{ }$ & $\sqrt{ }$ \\
\hline PPKec & $\sqrt{ }$ & $\sqrt{ }$ & $\sqrt{ }$ & $\sqrt{ }$ & $\sqrt{ }$ & $\sqrt{ }$ & $\sqrt{ }$ & $\sqrt{ }$ \\
\hline Eskportir & $\sqrt{ }$ & $\sqrt{ }$ & $\sqrt{ }$ & $\sqrt{ }$ & $\sqrt{ }$ & $\sqrt{ }$ & $\sqrt{ }$ & $\sqrt{ }$ \\
\hline \multicolumn{9}{|l|}{ Saluran 3} \\
\hline Petani & $\times$ & $\sqrt{ }$ & $\sqrt{ }$ & $\times$ & $\sqrt{ }$ & $\sqrt{ }$ & $x$ & $\sqrt{ }$ \\
\hline PBProv & $\sqrt{ }$ & $\sqrt{ }$ & $\sqrt{ }$ & $\sqrt{ }$ & $\sqrt{ }$ & $\sqrt{ }$ & $\sqrt{ }$ & $\sqrt{ }$ \\
\hline Eskportir & $\sqrt{ }$ & $\sqrt{ }$ & $\sqrt{ }$ & $\sqrt{ }$ & $\sqrt{ }$ & $\sqrt{ }$ & $\sqrt{ }$ & $\sqrt{ }$ \\
\hline \multicolumn{9}{|l|}{ Saluran 4} \\
\hline Petani & $\times$ & $\sqrt{ }$ & $\sqrt{ }$ & $\sqrt{ }$ & $\times$ & $\sqrt{ }$ & $\times$ & $\sqrt{ }$ \\
\hline PPKec & $\sqrt{ }$ & $\sqrt{ }$ & $\sqrt{ }$ & $\sqrt{ }$ & $\sqrt{ }$ & $\sqrt{ }$ & $\sqrt{ }$ & $\sqrt{ }$ \\
\hline Eskportir & $\sqrt{ }$ & $\sqrt{ }$ & $\sqrt{ }$ & $\sqrt{ }$ & $\sqrt{ }$ & $\sqrt{ }$ & $\sqrt{ }$ & $\sqrt{ }$ \\
\hline
\end{tabular}

Keterangan

PPDesa : Pedagang Pengumpul Desa

PPKec : : Pedagang Pengumpul Kecamatan

PBProv : Pedagang Besar Provinsi

$\sqrt{ } \quad:$ Melakukan Fungsi Pemasaran

$\times \quad$ : Tidak Melakukan Fungsi Pemasaran 
dan penjualan. Pedagang besar Provinsi melakukan penyimpanan pada gudang yang dimiliki sendiri untuk menampung biji kakao, sehingga terkumpul dalam jumlah banyak sebelum dijual.

\section{Eksportir}

Eksportir merupakan perusahaan atau lembaga yang memasarkan biji kakao ke pasar dunia. Pada tahun 2015 eksportir di Kota Palu tercatat sebanyak 9 perusahaan yang terdaftar di Asosiasi Kakao Indonesia untuk daerah Sulawesi Tengah (ASKINDO). Meskipun jumlah eksportir (biji kakao) di kota Palu tergolong sedikit, namun oleh karena semua eksportir bersaing dalam mendapatkan volume transaksi, sehingga bersaing dalam bermitra dengan pedagang besar dan pedagang kecamatan, maka pasar kakao di tingkat petani menjadi tampak seperti pasar bersaing. Ini didukung oleh informasi pasar yang tersedia, dan dapat diakses oleh pedagang hingga ke tingkat pedagang pengumpul. Di tingkat pedagang pengumpul, meskipun bentuk pasar tergolong oligopsoni, namun di antara pedagang satu dan lainnya bersaing untuk mendapatkan kakao biji. Oleh karena itu, harga di tingkat eksportir menjadi harga bersaing, dan pasar seakan-akan menjadi pasar bersaing, di mana penjual dan pembeli keduanya tidak dapat menentukan harga.

\section{Mekanisme Penentuan Harga dan Sistem Pembayaran}

Secara teknis, penentuan harga biji kakao berdasarkan pada tingkat kualitas biji kakao yang dipasarkan. Kualitas biji kakao meliputi kadar air, banyaknya biji per gram, kotoran serta jamur. Ditingkat eksportir penentuan harga dilakukan melalui tawar menawar antara eksportir dan buyers. Selain itu kerjasama yang telah terjalin meningkatkan kepercayaan buyer terhadap nilai harga yang ditetapkan oleh eksportir. Penentuan harga kakao ditingkat petani disetiap lembaga pemasaran terlihat pada Tabel 2.

\section{Saluran Pemasaran Biji Kakao}

Analisis saluran pemasaran akan menggambarkan macam saluran biji kakao yang dilalui dalam sistem

Tabel 2. Proses Penentuan Harga Biji Kakao pada Setiap Lembaga Pemasaran

\begin{tabular}{|c|c|c|}
\hline Lembaga Pemasaran & Sumber Informasi Harga & Proses Penentuan Harga \\
\hline Petani & $\begin{array}{l}\text { Pedagang pengumpul, } \\
\text { petani lain }\end{array}$ & $\begin{array}{l}\text { Ditentukan oleh } \\
\text { pedagang pengumpul }\end{array}$ \\
\hline Pedagang pengumpul desa & $\begin{array}{l}\text { pedagang pengumpul kecamatan, } \\
\text { pedagang besar provinsi }\end{array}$ & ditentukan oleh pedagang besar \\
\hline $\begin{array}{l}\text { Pedagang pengumpul } \\
\text { kecamatan }\end{array}$ & $\begin{array}{l}\text { eksportir, pedagang besar } \\
\text { provinsi }\end{array}$ & ditentukan oleh pedagang besar \\
\hline Pedagang besar provinsi & eksportir & tawar-menawar \\
\hline Eksportir & Pasar dunia, buyer & tawar-menawar \\
\hline
\end{tabular}


pemasaran. Berdasarkan data petani sampel $(n=80)$, pedagang pengumpul desa $(n=4)$, pedagang pengumpul kecamatan $(n=4)$, pedagang besar provinsi $(n=2)$ dan eksportir $(n=2)$ dapat digambarkan dalam saluran pemasaran. Terdapat 4 macam saluran pemasaran yang dilakukan petani di Kabupaten Parigi Moutong yaitu :

\section{Saluran 1 :}

Petani - pedagang pengumpul kecamatan - pedagang besar provinsi - eksportir

\section{Saluran 2 :}

Petani - pedagang pengumpul desa pedagang pengumpul kecamatan eksportir

\section{Saluran 3 :}

Petani - pedagang besar provinsi eksportir

\section{Saluran 4 :}

Petani - pedagang pengumpul kecamatan - eksportir

\section{Analisis Kinerja Pemasaran}

\section{Marjin Pemasaran}

Analisis marjin didalam penelitian ini mempergunakan akuntansi yang bertujuan untuk mengetahui penyebaran marjin pemasaran diantara lembaga-lembaga yang terlibat pada saluran pemasaran. Saluran pemasaran yang ada di Kabupaten Parigi Moutong yaitu 4 saluran, ini sejalan dengan penelitian yang dilakukan oleh Danil et al (2014). Besarnya marjin pada masing-masing saluran pemasaran berbeda-beda, tergantung pada saluran yang dilalui dan banyaknya lembaga pemasaran yang terlibat.

Hasil analisis menunjukkan bahwa saluran 1 biaya pemasaran terbesar dikeluarkan oleh eksportir yaitu sebesar Rp 2.941/kg, kemudian pedagang besar provinsi Rp 395/kg, dan yang terakhir tingkat pedagang pengumpul kecamatan Rp 918/kg. Besarnya biaya yang dikeluarkan oleh eksportir disebabkan oleh besarnya biaya tenaga kerja yang mencapai Rp 2.800/kg. Hasil analisis menunjukkan bahwa marjin pemasaran terbesar terdapat pada saluran 2 (petani pedagang pengumpul desa - pedagang pengumpul kecamatan - eksportir) yaitu Rp 25.465/kg, sedangkan saluran 3 merupakan saluran yang memiliki marjin pemasaran terkecil yaitu Rp 20. 715/kg.

Hasil analisis pada saluran 3 menunjkkan biaya pemasaran terbesar dikeluarkan oleh eksportir yaitu sebesar Rp 3.173/kg, sedangkan pada tingkat pedagang besar provinsi $\mathrm{Rp}$ $1.005 / \mathrm{kg}$. Besarnya biaya yang dikeluarkan oleh eksportir disebabkan oleh besarnya biaya tenaga kerja yang mencapai Rp 2.200/kg. Selain biaya teaga kerja, eksportir juga mengeluarkan baiaya transportasi, bongkar muat, retribusi, kemasan, sortir, bea cukai, dan administrasi. Hasil analisis menunjukkan bahwa saluran 4 biaya pemasaran terbesar dikeluarkan oleh eksportir yaitu sebesar Rp 3.457/kg, sedangkan pada tingkat pedagang pengumpul kecamatan Rp 918/kg. Besarnya biaya yang dikeluarkan oleh 
Tabel 3. Marjin dan Farmer Share Saluran Pemasaran di Kabupaten Parigi Moutong

\begin{tabular}{|c|c|c|c|c|c|}
\hline \multirow{2}{*}{ No } & \multirow{2}{*}{ Uraian (Rp/Kg) } & \multicolumn{4}{|c|}{ Saluran Pemasaran } \\
\hline & & 1 & 2 & 3 & 4 \\
\hline \multirow[t]{2}{*}{1} & Petani & & & & \\
\hline & a. Harga Jual & 26.188 & 23.875 & 28.626 & 26.833 \\
\hline \multirow[t]{6}{*}{2} & Pedagang Desa & & & & \\
\hline & a. Harga Beli & - & 23.875 & - & - \\
\hline & b. Biaya Pemasaran & - & 135,5 & - & - \\
\hline & c. Harga Jual & - & 26.750 & - & - \\
\hline & d. Keuntungan & - & 2.739 & - & - \\
\hline & e. Marjin Pedagang Desa & - & 2.875 & - & - \\
\hline \multirow[t]{6}{*}{3} & Pedagang Kecamatan & & & & \\
\hline & a. Harga Beli & 26.188 & 26.750 & - & 26.833 \\
\hline & b. Biaya Pemasaran & 918,5 & 785,5 & - & 918,5 \\
\hline & c. Harga Jual & 29.750 & 31.750 & - & 31.750 \\
\hline & d. Keuntungan & 2.643 & 4.214 & - & 2.998 \\
\hline & e. Marjin Pedagang Kecamatan & 3.562 & 5.000 & - & 4.917 \\
\hline \multirow[t]{6}{*}{4} & Pedagang Besar Provinsi & & & & \\
\hline & a. Harga Beli & 29.750 & - & 28.625 & \\
\hline & b. Biaya Pemasaran & 395,5 & - & 1.005 & - \\
\hline & c. Harga Jual & 32.500 & - & 32.500 & - \\
\hline & d. Keuntungan & 2.354 & - & 2.870 & - \\
\hline & e. Marjin Pedagang Besar Provinsi & 2.750 & - & 3.875 & - \\
\hline \multirow[t]{6}{*}{5} & Eksportir & & & & \\
\hline & a. Harga Beli & 32.500 & 31.750 & 32.500 & 31.750 \\
\hline & b. Biaya Pemasaran & 2.941 & 3.943 & 3.172 & 3.457 \\
\hline & c. Harga Jual & 49.340 & 49.340 & 49.340 & 49.340 \\
\hline & d. Keuntungan & 12.899 & 13.656 & 13.668 & 14.133 \\
\hline & e. Marjin Eksportir & 16.840 & 17.590 & 16.840 & 17.590 \\
\hline \multicolumn{2}{|c|}{ Total Biaya Pemasaran } & 4.255 & 4.864 & 41.77 & 5.294 \\
\hline \multicolumn{2}{|c|}{ Total Keuntungan } & 17.896 & 20.609 & 16.538 & 17.131 \\
\hline \multicolumn{2}{|c|}{ Total Marjin } & 23.152 & 25.465 & 20.715 & 22.507 \\
\hline
\end{tabular}

eksportir disebabkan oleh besarnya biaya tenaga kerja yang mencapai $\mathrm{Rp}$ $2.200 / \mathrm{kg}$. Selain biaya teaga kerja, eksportir juga mengeluarkan biaya transportasi, bongkar muat, retribusi, kemasan, sortasi, bea cukai, dan administrasi.

\section{Farmer Share}

Farmer Share merupakan rasio antara harga di tingkat petani terhadap harga di tingkat pedagang. Besarnya farmer share dipengaruhi oleh tingkat pemprosesan, biaya transportasi, keawetan produk dan jumlah produk (Kohls dan Uhl 2002). Di Kabupaten Parigi Moutong, share harga yang diterima petani relatif tinggi $(>49 \%)$. Share yang diterima petani di kabupaten ini relatif tinggi karena tidak adanya proses pengolahan yang dilakukan oleh tiap lembaga pemasaran, semua lembaga pemasaran yang dilalui pemasaran menjual kakao dalam bentuk biji, bahkan sampai eksportir menjual kakao dalam bentuk biji ke importir. Tabel 4 menunjukkan farmer share yang dihasilkan pada 
Tabel 4. Farmer Share pada Saluran Pemasaran di Kabupaten Parigi Moutong

\begin{tabular}{cccc}
\hline Saluran & \multicolumn{2}{c}{ Harga (Rp/Kg) } & Farmer Share \\
\cline { 2 - 4 } Pemasaran & Petani Kakao & Eksportir & (\%) \\
\hline Saluran 1 & 26188 & 49340 & 53.07 \\
Saluran 2 & 23875 & 49340 & 49.38 \\
Saluran 3 & 28626 & 49340 & 58.01 \\
Saluran 4 & 26833 & 49340 & 54.38 \\
\hline
\end{tabular}

setiap saluran pemasaran di Kabupaten Parigi Moutong.

Berdasarkan Tabel 4 terlihat bahwa saluran pemasaran 3 lebih efisien dibandingkan saluran lainnya dengan nilai farmer share sebesar 58.01 persen. Farmer Share dapat dikatakan sebagai bagian harga yang dibayar konsumen dan dinikmati oleh petani.

Berdasarkan hasil analisis farmer share di Kabupaten Parigi Moutong dapat disimpulkan bahwa share harga yang diterima petani baik di Kabupaten Parigi Moutong ter-golong tinggi. Hal ini dikarenakan lebih dari 50 persen petani menikmati harga yang dibayarkan oleh konsu-men. Dalam aktivitas pemasaran komoditas pertanian share harga yang diterima petani dapat mencapai 40 persen atau lebih dari harga yang dibayarkan oleh konsumen (Kohl dan Uhl 2002). Farmer Share yang tinggi menggambarkan tidak terlalu tingginya harga jual biji kakao di pasar ekspor sehingga bisa dinikmati oleh petani. Walaupun dalam memasarkan biji kakaonya petani terikat oleh pinjaman modal, dan penerima harga (price taker) tetapi tidak mempengaruhi share harga yang diterima petani. Hal ini sangat terkait dengan integrasi pasar yang terjadi. Oleh karena itu, berikut ini akan dianalisis apakah pasar kakao di tingkat petani terintegrasi dengan pasar kakao di tingkat eksportir.

\section{SIMPULAN DAN SARAN Simpulan}

Berdasarkan hasil penelitian yang telah dikemukakan sebelumnya, dapat dirangkumkan beberapa kesim-pulan sebagai berikut:

1. Analisis struktur pasar (market structure) biji kakao di Kabupaten Parigi Moutong cenderumg oligopoli. Pangsa pasar terbesar yaitu PT. Olam Indonesai dengan nilai pangsa pasar sebesar 24.16 persen. Pasar biji kakao di Kabupaten Parigi Moutong terkonsentrasi dengan tingkat persaingan yang kecil, hal ini ditunjukkan dengan nilai $\mathrm{CR}_{4}$ sebesar 0.70. Selain itu terdapat hambatan masuk dalam pemasaran biji kakao di Kabupaten Parigi Moutong, hal ini ditunjukkan dengan nilai rata-rata Minimum Efficiency Scale (MES) tahun 2009 2013 sebesar 22.65 persen.

2. Analisis perilaku pasar (market conduct) biji kakao di Kabupaten Parigi Moutong menunjukkan ter- 
dapat beberapa lembaga pemasaran yaitu petani, pedagang pengumpul desa, pedagang pengumpul kecamatan, pedagang besar provinsi serta eksportir, masing-masing lembaga pemasaran melakukan fungsi-fungsi pemasaran. Pada aktivitas pemasaran adanya ikatan permodalan yang dilakukan petani dengan pedagang pengumpul menyebabkan petani terbatas dalam memperoleh informasi harga. Sebanyak 50 persen terikat kontrak dengan pedagang pengumpul. Untuk hal penyortitan, hanya sebesar 22.5 persen petani yang melakukan penyortiran sebelum menjual biji kakao ke pedagang.

3. Analisis kinerja pasar (market performance) biji kakao di Kabupaten Parigi Moutong menunjukkan bahwa terdapat empat (4) saluran pemasaran dengan total marjin yang berbeda-beda. Total marjin yang tetinggi terdapat pada saluran 2 (petani-pedagang desa-pedagang kecamatan-eksportir) yaitu sebesar Rp 25 465, semakin banyak lembaga pemasaran yang terlibat maka marjin pemasaran semakin tinggi. Hal ini menyebabkan farmer share yang semakin rendah. Saluran pemasaran yang paling efisien adalah saluran pemasaran 3 dengan nilai farmer share sebesar 58.01 persen.

\section{Saran}

Diperlukan dukungan dan peran kelembagaan dengan adanya penguatan fungsi organisasi berupa koperasi untuk meningkatkan kinerja pemasaran kakao di Provinsi Sulawesi Tengah khususnya
Kabupaten Parigi Moutong yang memiliki fungsi melakukan koordinasi antar seluruh lembaga, dan menyampaikan informasi secara terbuka mengenai halhal yang terkait dengan pemasaran kakao.

\section{DAFTAR PUSTAKA}

Abbot, J.C dan J.P Mahekam. 1990. Agriculture Economics and Marketing In The Tropics. Longman. Essex.

Amalia DN. 2013. Sistem Pemasaran Karet Rakyat di Provinsi Jambi dengan Pendekatan Structure, Conduct, Performance (SCP). [tesis], Bogor (ID): Institut Pertanian Bogor.

Asmara R dan Ardhiani. 2010. Integrasi Pasar dalam Sistem Pemasaran Bawang Merah. Agrise, 10(3): 164-176.

Asmarantaka RW. 2012. Pemasaran Agribisnis (Agrimarketing). Departemen Agribisnis Fakultas Ekonomi dan Manajemen. IPB. Bogor.

Asmarantaka RW. 2008. Bahan Kuliah Pemasaran Pertanian. Program Studi Ilmu Pertanian sekolah Pascasarjana. IPB. Bogor.

[BPS] Badan Pusat Statistik, 2010. Sulawesi Tengah dalam Angka. Badan Pusat Statistik Provinsi Sulawesi Tengah.

2013. Kabupaten Parigi Moutong dalam Angka 2013. Sulawesi Tengah (ID): BPS

Baye M. 2010. Managerial Economics and Business Strategy. Seventh Edition. Mc Graw-Hill Irwin. Singapore. 
Besanko D, Dranove D, Shanley M dan Schaefar S. 2010. Economics of Strategy. Fifth Edition. International Student Version. John Wiley \& Sons. USA.

Bosena, Bekabil, Berhanu, dan Dirk. 2006. Structure-ConductPerformance of Cotton Market : The Case of Matema District, Ethiopia. Journal of Agricultural, Biotechnology \& Ecology, 4(1): 112.

Burhan MU, Suman, Pudjiharjo, Soetjipto. 2011. Analisis Ekonomi terhadap Struktur, Perilaku, dan Kinerja Pasar Pupuk di Jawa Timur (Kasus di Kabupaten Lumajang dan Kabupaten Ngawi). Journal of Indonesian Applied Economics, 5(1): 68-92.

Carlton DW dan Perlof JM. 2000. Modern Industrial Organization Third Edfition. Massachusetts (US): Addison-Wesley.

Dahl AD and Hammond 1997. Market and Price Analysis The Agriculture Industries. McGraw Hill, New York.

Danil, Firdaus , Hartoyo. 2014. Produksi dan Pemasaran Kakao di Kabupaten Padang Pariaman, Provinsi Sumatera Barat. Jurnal Manajemen dan Agribisnis, 11(1): 41-51.

[Ditjenbun] Direktorat Jenderal Perkebunan. 2014. Statistik Perkebunan Indonesia 2004-2006. Biji Kakao. Ditjenbun. Jakarta.

Downey, David W dan John K. Trocke. 1981. Agribusiness Management. McGraw-Hill, Inc.US of America.
Funke O, Raphel B, and Kabir S. 2012. Market structure, conduct anf performance of gari processing industry in South Western Nigeria. Europen Journal of Business and Management 4(2):99-112.

Hirschey. 2009. Fundamentals of Managerial Economics. Kansas (US): University of Kansas.

Jaya WK. 2001. Ekonomi Industri. Edisi Kedua. Fakultas Ekonomi. Universitas Gajah Mada. Yogyakarta.

Kizito. 2011. Evaluating the Impact on Market Performance of Investments in Market Information Systems: Methodological Challenges. Staff Paper: 1-14

Kohl dan Uhl. (2002), Marketing of Agricultural Product, Ninth Edition Prentice- Hall. 544 pp.

Nurhidayah. 2014. Analisis Struktur, Perilaku, dan Kinerja Pemasaran Jambu Mete Gelondongan di Kabupaten Muna Provinsi Sulawesi Tenggara. Tesis Magister Sains. Program Pascasarjana, Institut Pertanian Bogor, Bogor.

Rosiana N. 2012. Sistem Pemasaran Gula Tebu (Cane Sugar) Dengan Pendekatan Structure, Conduct, Performance (SCP)[Kasus : Perusahaan Perseroan (Persero) PT. Perkebunan Nusantara VII Unit Usaha Bungamayang].Tesis Magister Sains. Program Pascasarjana, Institut Pertanian Bogor, Bogor.

Waldman DE dan Jensen EJ. 2007. Industrial Organization. Theory and Practice. Third 
Yantu MR, Bambang J. Hermanto S, Isang G dan Setia H. 2011. Integrasi Pasar Kakao Biji Perdesaan Sulawesi Tengah dengan Pasar Dunia. Jurnal Agroekonomi 28(2): 201-225.

Yantu, M.R. 2008. Masalah Perdagangan Internasional Komoditi Kakao Indonesia: Suatu Tinjauan Kritis. Jurnal Agrokultur, 2(3): 89 - 98 


\section{Lampiran 1. Analisis Marjin Pemasaran dan Farmer Share Biji Kakao di Kabupaten Parigi Moutong}

\begin{tabular}{|c|c|c|c|c|c|}
\hline \multirow{2}{*}{ No } & \multirow{2}{*}{ Uraian (Rp/Kg) } & \multicolumn{4}{|c|}{ Saluran Pemasaran } \\
\hline & & 1 & 2 & 3 & 4 \\
\hline \multirow[t]{2}{*}{1} & Petani & & & & \\
\hline & a. Harga Jual & 26188 & 23875 & 28626 & 26833 \\
\hline \multirow[t]{9}{*}{2} & Pedagang Desa & & & & \\
\hline & a. Harga Beli & - & 23875 & - & - \\
\hline & b. Biaya Pemasaran & - & 135.5 & - & - \\
\hline & * Biaya Transportasi & - & 75 & - & - \\
\hline & *Biaya Kemasan (Karung, Tali rapiah) & - & 10.5 & - & - \\
\hline & * Tenaga Kerja & - & 50 & - & - \\
\hline & c. Harga Jual & - & 26750 & - & - \\
\hline & d. Keuntungan & - & 2739 & - & - \\
\hline & e. Marjin Pedagang Desa & - & 2875 & - & - \\
\hline \multirow[t]{12}{*}{3} & Pedagang Kecamatan & & & & \\
\hline & a. Harga Beli & 26188 & 26750 & - & 26833 \\
\hline & b. Biaya Pemasaran & 918.5 & 785.5 & - & 918.5 \\
\hline & * Biaya Transportasi, bongkar muat dan retribusi & 120 & 120 & - & 120 \\
\hline & * Biaya kemasan (karung, tali rapiah) & 10.5 & 10.5 & - & 10.5 \\
\hline & * Biaya susut & 523 & 535 & - & 523 \\
\hline & * Biaya penyimpanan + gudang & 50 & 50 & - & 50 \\
\hline & * Biaya sortasi & 75 & - & - & 75 \\
\hline & * Biaya tenaga kerja & 140 & 120 & - & 140 \\
\hline & c. Harga Jual & 29750 & 31750 & - & 31750 \\
\hline & d. Keuntungan & 2643 & 4214 & - & 2998 \\
\hline & e. Marjin Pedagang Kecamatan & 3562 & 5000 & - & 4917 \\
\hline \multirow[t]{12}{*}{4} & Pedagang Besar Provinsi & & & & \\
\hline & a. Harga Beli & 29750 & - & 28625 & - \\
\hline & b. Biaya Pemasaran & 395.5 & - & 1005 & - \\
\hline & * Biaya Transportasi, bongkar muat dan retribusi & 100 & - & 80 & - \\
\hline & * Biaya kemasan (karung, tali rapiah) & 10.5 & - & 10.5 & - \\
\hline & * Biaya susut & - & - & 572 & - \\
\hline & * Biaya penyimpanan + gudang & 110 & - & 83 & - \\
\hline & * Biaya sortasi & 75 & - & 120 & - \\
\hline & * Biaya tenaga kerja & 100 & - & 140 & - \\
\hline & c. Harga Jual & 32500 & - & 32500 & - \\
\hline & d. Keuntungan & 2354 & - & 2870 & - \\
\hline & e. Marjin Pedagang Besar Provinsi & 2750 & - & 3875 & - \\
\hline \multirow[t]{16}{*}{5} & Eksportir & & & & \\
\hline & a. Harga Beli & 32500 & 31750 & 32500 & 31750 \\
\hline & b. Biaya Pemasaran & 2941 & 3943 & 3172 & 3457 \\
\hline & * Biaya Transportasi, bongkar muat dan retribusi & 500 & 500 & 650 & 650 \\
\hline & * Biaya kemasan (karung, tali rapiah) & 16.5 & 16.5 & 20 & 20 \\
\hline & * Biaya tenaga kerja & 2800 & 2800 & 2200 & 2200 \\
\hline & * Biaya penyimpanan + gudang & 210 & 210 & 180 & 180 \\
\hline & * Biaya sortasi & 325 & 317.5 & 325 & 317.5 \\
\hline & * Biaya Administrasi + bea cukai & 90 & 90 & 90 & 90 \\
\hline & c. Harga Jual & 49340 & 49340 & 49340 & 49340 \\
\hline & d. Keuntungan & 12899 & 13656 & 13668 & 14133 \\
\hline & e. Marjin Eksportir & 16840 & 17590 & 16840 & 17590 \\
\hline & Total Biaya Pemasaran & 4255 & 4864 & 4177 & 5294 \\
\hline & Total Keuntungan & 17896 & 20609 & 16538 & 17131 \\
\hline & Total Marjin & 23152 & 25465 & 20715 & 22507 \\
\hline & Farmer Share & $53.07 \%$ & $49.38 \%$ & $58.01 \%$ & $54.38 \%$ \\
\hline
\end{tabular}


Ihdiani Abubakar, Dedi Budiman Hakim, dan Ratna Winandi Asmarantaka 